\title{
ANALISIS FAKTOR-FAKTOR YANG MEMPENGARUHI MOTIVASI MELAKUKAN PEMERIKSAAN PAP SMEAR PADA WANITA USIA SUBUR
}

\author{
Sri Aminingsih, Tunjung Sri Yulianti \\ STIKES PANTI KOSALA SURAKARTA, Sukoharjo, Jawa Tengah, Indonesia
}

\begin{abstract}
Abstrak
Latar Belakang. Salah satu penyebab kematian perempuan di Indonesia adalah kanker, salah satunya adalah kanker serviks. Menurut data Riskesdas tahun 2013 angka kejadian kanker di Jawa Tengah adalah 2,1\% dengan dengan 1,2\% adalah kanker serviks. Kanker serviks menelan banyak korban perempuan di Indonesia meskipun seharusnya dapat dicegah dengan melakukan upaya pencegahan dan deteksi dini, salah satunya dengan melaksanakan pemeriksaan pap smear.

Tujuan Penelitian. Mengetahui faktor-faktor yang mempengaruhi motivasi melakukan pemeriksaan pap smear pada pasangan usia subur.

Subjek dan Metode. Penelitian berupa analitik dengan desain korelasi. Populasi pada penelitian ini adalah wanita usia subur di Desa Wiragunan pada bulan September 2019 sampai Maret 2020 berjumlah 60 responden. Teknik sampling yang digunakan adalah teknik sampling jenuh. Hasil penelitian dianalisis menggunakan Uji Korelasi Chi-Square. Hasil Penelitian. Responden dengan pengetahuan tinggi adalah $44(73,33 \%)$ dan pengetahuan rendah 16 responden $(26,67 \%)$. Dukungan keluarga tinggi yaitu 43 responden $(71,67 \%)$, dukungan keluarga rendah 17 responden $(28,33 \%)$. Sedangkan responden dengan motivasi tinggi $42(70 \%)$ dan motivasi rendah $18(30 \%)$. Hasil analisis Chi Square tingkat pengetahuan $(p=0,001)$, dukungan keluarga $(p=0,01)$ terhadap motivasi melakukan pap smear.

Kesimpulan. Ada hubungan pengetahuan tentang kanker serviks dengan motivasi melakukan pemeriksaan pap smear pada wanita usia subur dan ada hubungan dukungan keluarga dengan motivasi melakukan pemeriksaan pap smear pada wanita usia subur
\end{abstract}

Kata kunci : dukungan keluarga, kanker serviks, motivasi, pap smear, pengetahuan

\section{ANALYSIS OF FACTORS AFFECTING MOTIVATION TO DO A PAP SMEAR EXAMINATION IN WOMEN OF CHILDBEARING AGE}

\begin{abstract}
Background. One cause of death of women in Indonesia is cancer, one of which is cervical cancer. According to the 2013 Riskesdas data the incidence of cancer in Central Java was $2.1 \%$ with $1.2 \%$ being cervical cancer. Cervical cancer swallows many female victims in Indonesia, although it should be prevented by making efforts to prevent and detect early, one of them by carrying out a pap smear examination.

The Aim of the Study. Knowing the factors that affecting motivation conducting pap smear examination in woman of childbearing age.

Subject and Method. The research was analytic correlation design. The population in this study were women of childbearing age in the village of Wiragunan in September 2019 to March 2020 totaling 60 respondents. The sampling technique used is saturation sampling technique. The results of the study were analyzed using the Chi-Square Correlation Test. Result. Respondents with high knowledge were 44 (73.33\%), who had low knowledge of 16 respondents (26.67\%). High family support there are 43 respondents $(71.67 \%)$, low family support 17 respondents (28.33\%). While respondents with high motivation 42 $(70 \%)$ and low motivation 18 (30\%). The results of the Chi Square analysis of the level of knowledge $(p=0.001)$, family support $(p=0.001)$ on the motivation to do the pap smear.
\end{abstract}


Conclusion. There is a relationship of knowledge about cervical cancer with the motivation to conduct pap smears in women of childbearing age. And there is a relationship of family support with the motivation to do a pap smear test on women of childbearing age.

Keywords : cervical cancer, family support, knowledge, motivation, pap smear test

Korespondensi: Sri Aminingsih. STIKES PANTI KOSALA SURAKARTA. Jalan Raya Solo - Baki Km. 4 Gedangan, Grogol, Sukoharjo, Jawa Tengah.

Email: s.aminingsih@yahoo.co.id.

\section{LATAR BELAKANG}

Salah satu masalah kesehatan pada wanita yang menyebabkan kematian cukup tinggi di Indonesia adalah kanker, salah satunya adalah kanker serviks. Menurut data Riskesdas tahun 2013 angka kejadian kanker di Jawa Tengah adalah 2,1\% dengan 1,2\% adalah kanker serviks. Kanker serviks merupakan salah satu jenis kanker yang semestinya dapat dicegah dengan melakukan upaya pencegahan dan deteksi dini. Bila kanker serviks ditemukan pada tahap awal maka dapat diharapkan penyembuhannya berlangsung secara maksimal. Dengan demikian dapat dikatakan bahwa kematian yang terjadi pada perempuan karena kanker serviks adalah kematian yang sia - sia (Nurwijaya dan Suheimi, 2010).

Lebih dari $30 \%$ penyakit kanker dapat dicegah dengan cara mengubah faktor resiko perilaku dan pola makan penyebab penyakit kanker. Kanker yang diketahui sejak dini memiliki kemungkinan untuk mendapatkan penanganan yang lebih baik. Oleh karena itu, perlu dilakukan upaya pencegahan untuk meningkatkan kesadaran masyarakat dalam mengenali gejala dan risiko penyakit kanker sehingga dapat menentukan langkah langkah pencegahan dan deteksi dini yang tepat (Kemenkes RI, 2015).

Pengetahuan seseorang tentang kanker serviks yang didapatkan ketika seseorang melakukan pengindraan terhadap suatu objek tertentu akan diterapkan pada sikap yang lahir dari dalam diri sendiri termasuk melakukan deteksi dini kanker serviks dengan cara melakukan pap smear. Pengetahuan berpengaruh terhadap pola pikir PUS mengenai kanker serviks seperti pengertian kanker serviks, penyebab dan faktor resiko, pencegahan, gejala dan deteksi dini kanker serviks (Oktavyany, Yusriana dan Ratnaningsih, 2015).

Kanker leher rahim atau kanker servik adalah salah satu masalah kesehatan terkemuka yang mencolok bagi perempuan di seluruh dunia dengan perkiraan 529.409 kasus baru dan sekitar 89 persen di negara-negara berkembang. Pekerjaan rumah tangga dan jumlah anak dalam keluarga di negara berkembang yang memerlukan perhatian menjadi alasan sebagian besar perempuan cenderung mengabaikan status kesehatan diri sendiri (Rahayu, 2015).

Kanker serviks merupakan penyebab utama kematian diantara perempuan di seluruh dunia. Diperkirakan bahwa 274.000 kematian terjadi setiap tahun akibat penyakit yang dapat dicegah ini. Para wanita dari masyarakat miskin sebagian besar dipengaruhi oleh kondisi ini. Hal ini dibuktikan bahwa sekitar $85 \%$ dari semua kematian akibat kanker serviks dilaporkan berasal dari negara berkembang 
(Rahayu, 2015). Kondisi ini mempengaruhi tidak hanya kesehatan dan kehidupan perempuan, tetapi anak-anak mereka, keluarga dan masyarakat pada umumnya.

Berdasarkan hasil penelitian yang dilakukan oleh Salmah, Rajab dan Djulaeha (2013), pemeriksaan pap smear merupakan salah satu metode deteksi dini terhadap kanker leher rahim pada tahap awal, secara umum pemeriksaan pap smear telah menurunkan insiden dan angka kematian secara efektif dan jika pemeriksaan pap smear dilakukan secara teratur dapat menurunkan resiko kematian akibat kanker leher rahim sebesar $90 \%$. Namun perilaku melakukan pemeriksaan pap smear ini masih belum banyak, sebagai contoh di komplek perumahan Graha Prima Tambun Utara Kabupaten Bekasi menunjukan WUS (Wanita Usia Subur) yang tidak melakukan pap smear lebih banyak, yaitu 36 responden (72\%) dan 14 responden (28\%) saja yang melakukan pemeriksaan pap smear.

Serupa dengan hasil penelitian Farida dan Nurhidayah (2017), yang berjudul pengetahuan kanker serviks dalam tindakan melakukan pap smear pada Wanita Usia Subur di Desa Tulungrejo, didapatkan kesimpulan bahwa hampir setengah dari responden yang memiliki pengetahuan kurang belum pernah melakukan tindakan pap smear, yaitu sebanyak 36 responden (70,6\%), jadi hasil nilai $p=0,034$ artinya ada hubungan antara pengetahuan tentang kanker serviks dengan tindakan melakukan pap smear pada Wanita Usia Subur di Desa Tulungrejo Kecamatan Besuki Kabupaten Tulungagung.

Adapun hasil penelitian yang dilakukan oleh Linadi (2014), yang berjudul dukungan suami mendorong keikutsertaan pap smear Pasangan Usia Subur (PUS) di perumahan Pucang Gading
Semarang dengan sampel sebanyak 75 responden diketahui dukungan suami dan pengetahuan memiliki hubungan signifikan terhadap keikutsertaan pap smear $(p<0,05)$. Sedangkan variabel sikap memiliki sedikit hubungan $(p=0,066)$.

Pada observasi awal terhadap 2 WUS di desa Wirogunan Kartasura, didapatkan responden yang memiliki pengetahuan tentang kanker serviks sebanyak 1 orang dan responden yang takut untuk pemeriksaan pap smear sebanyak 1 orang dikarenakan dari keluarga juga belum ada yang berpengalaman dalam melakukan pemeriksaan pap smear.

Penelitian ini adalah replikasi dari penelitian sebelumnya meskipun ada sedikit perbedaan variabel yaitu tentang dukungan keluarga sedangkan yang akan diteliti pada penelitian ini adalah pengetahuan tentang kanker serviks dan dukungan keluarga dengan motivasi melakukan pemeriksaan pap smear pada Wanita Usia Subur.

Berdasarkan latar belakang masalah di atas maka peneliti tertarik untuk melakukan penelitian tentang "Hubungan Pengetahuan tentang Kanker Serviks dan Dukungan Keluarga dengan Motivasi Melakukan Pemeriksaan Pap Smear pada Wanita Usia Subur".

\section{TUJUAN PENELITIAN}

Mengetahui hubungan pengetahuan tentang kanker serviks dan dukungan keluarga dengan motivasi melakukan pemeriksaan pap smear pada Wanita Usia Subur.

\section{DESAIN PENELITIAN}

Pada penelitian ini penulis menggunakan desain penelitian korelasi dengan pendekatan cross sectional. 
POPULASI, SAMPEL DAN TEKNIK SAMPLING

Populasi pada penelitian ini adalah Wanita Usia Subur di Desa Wiragunan pada bulan September 2019 sampai Maret 2020 berjumlah 60 responden. Teknik sampling yang digunakan dalam penelitian ini adalah dengan teknik sampling jenuh. Analisa data menggunakan uji Chi Square.

\section{HASIL PENELITIAN}

Tabel 1.

Distribusi Frekuensi Responden

Berdasarkan Umur, Pekerjaan dan Pendidikan

\begin{tabular}{lcc}
\hline $\begin{array}{l}\text { Karakteristik } \\
\text { Responden }\end{array}$ & $\mathrm{f}$ & $\%$ \\
\hline Umur & & \\
$21-27$ & 14 & 23,33 \\
$28-35$ & 46 & 76,67 \\
Pekerjaan & & \\
Bekerja & 42 & 70 \\
Tidak Bekerja & 18 & 30 \\
Pendidikan & & \\
Pend.Dasar & 27 & 45 \\
Pend.Lanjut & 33 & 55 \\
\hline
\end{tabular}

Dari Tabel 1 di atas diperoleh informasi bahwa responden dengan kelompok umur terbanyak adalah 28-35 tahun berjumlah 46 responden $(76,67 \%)$, yang bekerja terbanyak adalah 42 responden $(70 \%)$ dan riwayat pendidikan lanjut terbanyak adalah 33 responden $(55 \%)$

Tabel 2.

Hasil Analisa Univariat

\begin{tabular}{lcc}
$\begin{array}{l}\text { Karakteristik } \\
\text { Responden }\end{array}$ & $\mathrm{f}$ & $\%$ \\
\hline $\begin{array}{l}\text { Pengetahuan } \\
\text { Rendah }\end{array}$ & 16 & 26,67 \\
$\begin{array}{l}\text { Tinggi } \\
\text { Dukungan }\end{array}$ & 44 & 73,33 \\
Keluarga & & \\
Rendah & 17 & 28,33 \\
Tinggi & 43 & 71,67 \\
Motivasi & & \\
Rendah & 18 & 30 \\
Tinggi & 42 & 70 \\
\hline
\end{tabular}

Dari Tabel 2 di atas diperoleh informasi bahwa responden yang memiliki pengetahuan terbanyak adalah pengetahuan tinggi berjumlah 44 responden $(73,33 \%)$, dukungan keluarga terbanyak adalah dukungan tinggi sebanyak 43 responden $(71,67 \%)$ dan memiliki motivasi terbanyak adalah motivasi tinggi 42 responden (70\%).

Tabel 3.

Hasil Tabulasi Silang

Hubungan Pengetahuan tentang

Kanker Serviks dengan Motivasi

Melakukan Pemeriksaan Pap Smear

\begin{tabular}{lccc}
\hline \multirow{2}{*}{ Pengetahuan } & \multicolumn{2}{c}{ Motivasi } & \multirow{2}{*}{$p$} \\
\cline { 2 - 3 } & Tinggi & Rendah & \\
\hline Tinggi & 42 & 2 & 0,001 \\
Rendah & 0 & 16 & \\
Total & 42 & 18 & \\
\hline
\end{tabular}

Berdasarkan hasil uji Chi-Square diperoleh $p$ sebesar 0,001 sehingga nilai $p<0,05$, yang berarti $\mathrm{H}_{\mathrm{o}}$ ditolak dan $\mathrm{H}_{\mathrm{a}}$ diterima, sehingga ada hubungan antara pengetahuan tentang kanker serviks dengan motivasi melakukan pemeriksaan pap smear.

Tabel 4.

Hasil Tabulasi Silang

Hubungan Dukungan Keluarga endahdengan Motivasi Melakukan Pemeriksaan Pap Smear

\begin{tabular}{lccc}
\hline \multirow{2}{*}{$\begin{array}{l}\text { Dukungan } \\
\text { Keluarga }\end{array}$} & \multicolumn{2}{c}{ Motivasi } & $p$ \\
\cline { 2 - 4 } & Tinggi & Rendah & \\
\hline Tinggi & 42 & 1 & 0,001 \\
Rendah & 0 & 17 & \\
Total & 42 & 18 & \\
\hline
\end{tabular}

Berdasarkan hasil uji Chi-Square diperoleh $p$ sebesar 0,001 sehingga nilai $p<0,05$, yang berarti $\mathrm{H}_{\mathrm{o}}$ ditolak dan $\mathrm{H}_{\mathrm{a}}$ diterima, sehingga ada hubungan antara dukungan keluarga dengan motivasi melakukan pemeriksaan pap smear. 


\section{PEMBAHASAN}

Berdasarkan analisa multivariat diperoleh hasil bahwa pengetahuan tentang kanker serviks dan dukungan keluarga secara bersama-sama tidak berpengaruh terhadap motivasi melakukan pemeriksaan pap smear. Maka peneliti akan melakukan pembahasan berdasarkan hasil analisa bivariat.

Dari hasil penelitian Hubungan Pengetahuan tentang kanker serviks dengan motivasi melakukan pemeriksaan pap smear diperoleh hasil uji Chi-Square p sebesar 0,001 sehingga nilai $p<0,05$, yang berarti $\mathrm{H}_{\mathrm{o}}$ ditolak dan $\mathrm{H}_{\mathrm{a}}$ diterima yaitu ada hubungan antara pengetahuan tentang kaker serviks dengan motivasi melakukan pemeriksaan pap smear.

Hasil penelitian ini dapat dicermati bahwa persentase pada pengetahuan dengan kategori rendah sebanyak $26,67 \%$ dan tinggi sebanyak $73,33 \%$. Hal ini membuktikan bahwa pengetahuan WUS tentang kanker serviks di Desa Wiragunan adalah tinggi. Menurut Fitriani (2011), pengetahuan adalah hasil "tahu", dan ini terjadi setelah orang melakukan pengindraan terhadap suatu objek tertentu. Pengindraan terjadi melalui panca indera manusia, yakni indera penglihatan, pendengaran, penciuman, rasa dan raba. Sebagian besar pengetahuan diperoleh melalui mata dan telinga. Sedangkan menurut Notoatmodjo (2011), pengetahuan atau kognitif merupakan domain yang sangat penting untuk terbentuknya tindakan seseorang (overt behavior). Karena dari pengalaman dan penelitian ternyata perilaku yang didasarkan oleh pengetahuan akan lebih langgeng daripada perilaku yang tidak didasari oleh pengetahuan. Teori tersebut memperkuat hasil penelitian ini bahwa dengan adanya pengetahuan tentang kanker serviks akan mendorong dan memotivasi WUS untuk melakukan pemeriksaan pap smear.

Menurut Wawan dan Dewi (2011), faktor yang mempengaruhi pengetahuan meliputi faktor internal dan eksternal, adapun faktor internal meliputi pendidikan, umur dan pekerjaan. Dalam penelitian ini pendidikan yang dimiliki oleh responden yaitu SMA sampai Perguruan Tinggi sebanyak 33 responden $(55 \%)$, umur responden antara 28-35 tahun sebanyak 46 responden $(76,67 \%)$, sedangkan responden yang bekerja sebanyak 42 (70\%). Semakin cukup umur, tingkat kematangan dan kekuatan seseorang akan lebih matang dalam berfikir dan bekerja. Dari segi kepercayaan masyarakat, seseorang yang lebih dewasa akan lebih mendapatkan kepercayaan dari orang lain apalagi didukung dengan tingkat pendidikan dan pekerjaan yang seringkali akan mendukung pengalaman dan kematangan jiwa seseorang dalam hal ini adalah memiliki motivasi untuk melakukan pemeriksaan pap smear.

Penelitian ini setipe dengan penelitian yang dilakukan oleh Oktavyany, Yusriana dan Ratnaningsih (2015), menunjukkan adanya hubungan yang signifikan antara pengetahuan PUS tentang kanker serviks dengan sikap terhadap pemeriksaan pap smear. Sedangkan penelitian lain yang dilakukan oleh Maulina (2012), menunjukkan bahwa terdapat hubungan yang bermakna antara pendidikan terhadap pengetahuan, informasi dan umur.

Penelitian lain dari Salmah, Rajab dan Djulaeha (2013), menunjukkan bahwa pendapatan, pengetahuan, sikap, dan dukungan sosial merupakan faktor dominan yang mempengaruhi perilaku pemeriksaan pap smear pada WUS, dimana faktor yang paling dominan 
adalah dukungan sosial (OR 13,63; $95 \%, \mathrm{Cl}: 2,60-71,46)$. Hal ini sesuai dengan teori yang diungkapkan oleh Wawan dan Dewi (2010), hubungan komponen afektif dengan komponen kognitif konsisten, bila komponen afektifnya berubah maka komponen kognitifnya berubah, demikian juga sebaliknya. Komponen kognitif ini mencakup pengetahuan, pandangan, kepercayaan tentang lingkungan, tentang seseorang atau tentang tindakan. Teori tersebut juga mendukung hasil dari penelitian ini bahwa pengetahuan tentang kanker serviks berhubungan dengan motivasi melakukan pemeriksaan pap smear dimana terdapat 44 responden $(73,33 \%)$ yang memiliki pengetahuan tinggi tentang kanker servik dan sebanyak 42 responden $(70 \%)$ memiliki motivasi tinggi untuk melakukan pap smear. Oleh karena itu apabila seseorang memiliki pengetahuan dalam hal ini adalah kanker serviks maka akan mempunyai keinginan atau motivasi untuk melakukan pencegahan dengan cara melakukan pemeriksaan pap smear.

Dari hasil penelitian Hubungan dukungan keluarga dengan motivasi melakukan pemeriksaan pap smear diperoleh hasil uji Chi-Square diperoleh $p$ sebesar 0,001 sehingga nilai $p<0,05$, yang berarti $\mathrm{H}_{\mathrm{o}}$ ditolak dan $\mathrm{H}_{a}$ diterima yaitu ada hubungan antara dukungan keluarga dengan motivasi melakukan pap smear.

Hasil penelitian ini diketahui bahwa persentase dukungan keluarga rendah sebanyak $28,33 \%$ dan dukungan keluarga tinggi sebanyak $71,67 \%$. Hal ini membuktikan bahwa sebagian besar WUS di desa Wiragunan mendapatkan dukungan dari keluarga untuk melakukan pemeriksaan pap smear. Dukungan keluarga merupakan salah satu bentuk kekuatan dari anggota keluarga dalam mengahadapi masalah kesehatan. Kekuatan keluarga menurut Muhlisin (2012), adalah kemampuan baik potensial atau aktual dari individu untuk mengendalikan atau mempengaruhi untuk merubah orang lain ke arah positif.

Menurut Duvall dan Miller sebagaimana dikutip oleh Muhlisin (2012), menguraikan bahwa keluarga adalah sekumpulan orang dengan ikatan perkawinan, kelahiran dan adopsi yang bertujuan menciptakan, mempertahankan budaya dan meningkatkan perkembangan fisik, mental, emosional serta sosial dari tiap anggota keluarga. Faktor yang mempengaruhi motivasi menurut Donsu (2017), terdiri dari faktor ekstrinsik yaitu hubungan antar manusia, imbalan dan kondisi lingkungan, sedangkan faktor intrinsik yaitu berprestasi, pengakuan dan kemajuan tingkat kehidupan. Adapun faktor yang mempengaruhi dukungan keluarga terdiri dari faktor internal meliputi dukungan istri, suami, saudara kandung atau dukungan anak. Sedangkan faktor eksternal adalah sahabat, pekerjaan, tetangga, sekolah, keluarga besar, kelompok sosial, kelompok rekreasi, tempat ibadah dan praktisi kesehatan. Keluarga merupakan sistem yang terbuka sehingga dapat dipengaruhi oleh supra sistemnya yaitu lingkungannya (masyarakat), dan sebaliknya sebagai sub sistem dari lingkungan (masyarakat), keluarga dapat mempengaruhi masyarakat (supra sistem). Oleh karena itu sangat penting peran dan fungsi keluarga dalam membentuk manusia sebagai anggota masyarakat yang sehat bio-psikososial-spiritual (Muhlisin, 2012). Dari teori tersebut sangat jelas dinyatakan bahwa dukungan dari keluarga baik istri, suami, anak bahkan keluarga besar dapat meningkatkan dorongan atau keinginan anggota keluarga untuk mempertahankan kesehatan 
sehingga muncul motivasi untuk melakukan suatu tindakan yaitu melakukan pemeriksaan pap smear. Apabila wanita usia subur di setiap keluarga mau melakukan pap smear maka pencegahan terjadinya kanker serviks bisa dilakukan lebih dini.

Penelitian yang serupa yang dilakukan Enggayati dan Idaningsih (2017), ada hubungan antara pengetahuan $(p=0,001)$, pendidikan $(p=0,001)$ dan dukungan keluarga $(p=0,006)$ dengan pelaksanaan papsmear pada PUS di wilayah kerja UPTD. Penelitian lain dilakukan oleh Puspitasari, Martini dan Wahyuni (2018), dengan hasil ada hubungan antara pengetahuan, biaya, tempat pelayanan, dan dukungan keluarga dengan perilaku pemeriksaan pap smear. Sedangkan penelitian yang dilakukan oleh Rahmawati (2019), ada hubungan antara peran keluarga dengan pemeriksaan pap smear pada WUS $(p=0,001)$.

Menurut Muhlisin (2012), family approach (pendekatan keluarga) diarahkan pada penggalian dan pemberdayaan potensi keluarga baik secara mandiri maupun dengan bantuan orang lain untuk mengatasi masalah-masalah kesehatan yang dihadapi oleh keluarga/anggota keluarga. Keluarga juga berfungsi untuk melaksanakan praktek asuhan kesehatan, yaitu untuk mencegah terjadinya gangguan kesehatan dan/atau merawat anggota keluarga yang sakit. Kemampuan keluarga dalam memberikan asuhan kesehatan mempengaruhi status kesehatan keluarga. Kesanggupan keluarga melaksanakan pemeliharaan kesehatan dapat dilihat dari tugas kesehatan keluarga yang dilaksanakan. Keluarga yang dapat melaksanakan tugas kesehatan berarti sanggup menyelesaikan masalah kesehatan keluarga. Teori tersebut sesuai dengan hasil penelitian ini bahwa dukungan keluarga berhubungan dengan motivasi melakukan pap smear dimana terdapat 43 responden $(71,67 \%)$ dengan dukungan yang tinggi dari keluarga dan terdapat 42 responden $(70 \%)$ yang memiliki motivasi tinggi untuk melakukan pemeriksaan pap smear, dengan adanya pendekatan dan pemberdayaan potensi pada setiap anggota keluarga maka masalah kesehatan yang akan terjadi dalam suatu keluarga pasti dapat dihindari sebab setiap anggota keluarga mempunyai keinginan untuk melakukan tindakan pencegahan terhadap masalah kesehatan yang bisa dihadapi oleh anggota keluarga seperti terjadinya kanker serviks yang salah satu pencegahannya adalah dengan melakukan tindakan pemeriksaan pap smear.

\section{KESIMPULAN}

Hasil penelitian ini diperoleh kesimpulan ada hubungan pengetahuan tentang kanker serviks dengan motivasi melakukan pemeriksaan pap smear $(p=0,001)$ dan ada hubungan dukungan keluarga dengan motivasi melakukan pemeriksaan pap smear $(p=0,001)$, sedangkan pengetahuan tentang kanker serviks dan dukungan keluarga secara bersama-sama tidak berpengaruh terhadap motivasi melakukan pemeriksaan pap smear $(p=1,000)$.

\section{SARAN}

Diharapkan petugas kesehatan melakukan penyuluhan tentang kanker serviks untuk meningkatkan motivasi dan kesadaran Wanita Usia Subur dalam melakukan pemeriksaan pap smear. Selain itu diharapkan pula bahwa keluarga mampu meningkatkan peran sertanya dalam memberikan dukungan bagi Wanita Usia Subur untuk melakukan pemeriksaan pap smear. 
DAFTAR PUSTAKA

Donsu, J.D.T. 2017. Psikologi Keperawatan. Pustaka baru Press, Yogyakarta.

Enggayati, N.T. dan Ayu I. 2017. Faktor-faktor yang berhubungan dengan Pelaksanaan Papsmear Wanita PUS > 25 Tahun di UPTD Puskesmas DTP Maja Kabupaten Majalengka Tahun 2015. Midwife Journal. Vol 3. Diakses tanggal 15 Mei 2020.

Farida dan Firda O.N. 2017. Pengetahuan Kanker Serviks Dalam Tindakan Melakukan Pap Smear pada Wanita Usia Subur. Jurnal of Nursing Practice. Vol. 1. Diakses pada tanggal 3 Maret 2019.

Fitriani, S. 2011. Promosi Kesehatan. Graha IImu, Yogyakarta.

Kementerian Kesehatan RI. 2015. Stop Kanker. Dilihat 8 April 2015 , www.depkes.go.id>infodatinkanker.

Linadi, K. E. 2013. Dukungan Suami Mendorong Keikutsertaan Pap smear Pasangan Usia Subur (PUS) di Perumahan Pucang Gading Semarang.

Maulina, R. 2012. Faktor-Faktor Yang Berubungan Dengan Pengetahuan Tentang Pap Smear Pada Wanita Usia Subur (WUS) Di Kemukiman Lamnga Kecamatan Mesjid Raya Kabupaten Aceh Besar. Jurnal Kesehatan Masyarakat. Diakses pada tanggal 3 Maret 2019.

Muhlisin, A. 2012. Keperawatan Keluarga. Gosyen Publishing, Yogyakarta.

Nurwijaya, H. dan Suheimi K. 2010. Cegah dan Deteksi Kanker Serviks. PT. Elex Media Komputindo, Jakarta.
Notoatmodjo S. 2011. Kesehatan Masyarakat IImu \& Seni. Rineka Cipta, Jakarta.

Oktaviany, S., Chinthia S. Y. dan Dwi R. 2015. Hubungan Tingkat Pengetahuan Tentang Kanker Serviks Dengan Sikap Terhadap Pemeriksaan Pap Smear pada PUS Di Pukesmas Semanu Gunung Kidul. Jurnal Permata Indonesia. Vol. 6. Diakses pada tanggal 3 Maret 2019.

Puspitasari, D., Titin, M. dan Titis W. 2018. Pengaruh Dukungan Keluarga Terhadap Pemeriksaan Pap Smear pada Wanita Usia Subur di Puskesmas Wilayah Kabupaten Tangerang. Jurnal JKFT. Vol 3. Diakses tanggal 15 Mei 2020.

Rahmawati, N. V. 2019. Hubungan Peran Keluarga dengan Pemeriksaan Pap Smear pada Wanita Usia Subur di Dusun Bulu Desa Mantup Kecamatan Mantup Kabupaten Lamongan. Jurnal SURYA. Vol 11. Diakses tanggal 15 Mei 2020.

Rahayu, D. S. 2015. Asuhan Ibu dengan Kanker Serviks. Salemba Medika, Jakarta.

Riskesdas. 2013. Badan penelitian dan pengembangan kesehatan kementrian kesehatan RI tahun 2013. Jakarta.

Salmah, W. R. dan Eha, D. 2013. Faktor yang Berhubungan Dengan Perilaku Pemeriksaan Pap Smear Pada Wanita Usia Subur. Jurnal IImu \& Teknologi IImu Kesehatan. Diakses pada tanggal 3 Maret 2019.

Wawan, A dan Dewi, M. 2010. Teori \& Pengukuran Pengetahuan, Sikap, dan Perilaku Manusia. Nuha Medika, Yogyakarta. 